\title{
Evaluation of Bitter Gourd (Momordica charantia L.) Hybrids under Eastern Dry Zone of Karnataka, India
}

\author{
B. Sureshkumara ${ }^{1 *}$, T.B. Puttaraju ${ }^{2}$ and H.B. Pavithra ${ }^{3}$ \\ ${ }^{1}$ College of Horticulture, UHS Campus, GKVK Bengaluru, Karnataka, India \\ ${ }^{2}$ Department of Horticulture, University of Agricultural Sciences, Bagalkot, Karnataka, India \\ ${ }^{3}$ College of Agriculture, UAS Campus, GKVK Bengaluru, Karnataka, India \\ *Corresponding author
}

\section{A B S T R A C T}

\section{Keywords}

Bitter gourd, Vine length, Per cent fruit set, Yield per vine.

\section{Article Info}

Accepted: 15 September 2017 Available Online: 10 November 2017
The experiment was conducted at University of Agricultural Sciences, GKVK, Bengaluru, India to study the performance of 24 bitter gourd hybrids. Among these hybrids Coimbatore Long $\mathrm{x}$ Panurthy was recorded highest yield per vine $(2.32 \mathrm{~kg})$, average fruit weight $(85.10 \mathrm{~g})$, per cent fruit set (93.28), days to opening of first male flower appearance (37.32 days), day to fifty per cent flowering (83.12 days) and days to first harvest (64.07 days). Lesser number of seeds fruit ${ }^{-1}$ was recorded in Arka Harit x Coimbatore Small (12.30), maximum average fruit length in Green Long x Panurthy $(25.15 \mathrm{~cm})$, maximum sex ratio was recorded in Green Long $x$ Nanjangood Local. Maximum productive vine length was recorded in White Long x Panurthy at 45 DAS $(114.47 \mathrm{~cm}), 60$ DAS $(159.91 \mathrm{~cm})$ and 90 DAS $(296.28 \mathrm{~cm})$.

\section{Introduction}

Bitter gourd (Momordica charantia L.; $2 \mathrm{n}=$ $2 \mathrm{x}=22$ ), which belongs to family Cucurbitaceae, is an important vegetable mainly valued for its nutritional and medicinal properties. The origin of this crop is probably India with secondary centre of diversity in China (Grubben, 1977). It is widely cultivated in India, China, Malaysia, Africa, and South America (Minraj et al., 1993; Singh, 1990). Bitter gourd has been used for centuries in the ancient traditional medicine of India, China, Africa, and Latin America. Bitter gourd fruits also possess antioxidant, anti-microbial, anti-viral, antidiabetic activities (Welihinda et al., 1986;
Raman and Lau, 1996). Being a monoecious and highly cross-pollinated crop, large variation is observed in fruit and vegetative characters. Among the cucurbits, it is considered a prized vegetable because of its high nutritive value especially ascorbic acid and iron (Behera, 2004).

It is one of the most important cucurbitaceous crops due to its potential to return profit, nutritional value, and production potential. It is often grown during the rainy season and is economically important to both small and marginal farmers. Variation in bitter gourd is mostly found in shape, size, color, 
cucurbitacin content, and number of tubercles. All genotypes need to be examined for identification of superior genotypes. Bitter gourd cultivars grown in India have low average yields due to undesirable cultivars or hybrids, genetic drift in cultivars, and development of new races of pathogens. Hence, we have done an experiment to development and identification of suitable bitter gourd hybrids for Eastern Dry Zone of Karnataka.

\section{Materials and Methods}

The present investigation was undertaken at Gandhi Krishi Vignana Kendra, University of Agricultural Sciences, Bangalore. The research station is located at $12^{0} 59^{\circ}$ north latitude and $77^{\circ} 35^{\circ}$ East longitude with an elevation of about $930 \mathrm{~m}$ above mean sea level (MSL). The soil of the experimental site was red sandy loam (alfisol).

The experiment plot was ploughed twice, harrowed and passing cultivator thrice to remove weeds and crush the clods. Experimental field was made into required plot size and levelled after incorporation of FYM at the rate of $25 \mathrm{t} \mathrm{ha}^{-1}$. The spacing maintained between rows was $1.5 \mathrm{~m}$ and between plants $0.75 \mathrm{~m}$. Fifty per cent of recommended nitrogenous fertilizer @62.5 $\mathrm{kg} \mathrm{ha}^{-1}$ and full dose of $\mathrm{P}_{2} \mathrm{O}_{5} @ 50 \mathrm{~kg} \mathrm{ha}^{-1}$ in the form of urea and super phosphate applied in the furrow. Seeds were soaked in water for 24 hours and sown in portable cellular trays which were filled with mixture of coir pith and FYM in equal proportion. Four weeks old seedlings were transplanted to the main field at one seedling per hill. Light irrigation was given prior to transplanting and one day after transplanting. Weeding was done whenever necessary. The crop was irrigated once in four days and other cultural practices were followed as per the package of practices of horticultural crops of University of
Agricultural Sciences, Bangalore (Anon., 2013). Seven feet wooden poles were fixed at a distance 20 feet and three lines of galvanised wire of $16 \mathrm{~mm}$ gauge and tied to the fixed poles and as and when vine grows, the vines were trailed on the wire and loosely tied with jute thread.

The experimental material comprised of six lines $\left(\mathrm{L}_{1}\right.$ :VRBT-100, $\mathrm{L}_{2}$ :Arka Harit, $\mathrm{L}_{3}$ :White Long, $\mathrm{L}_{4}$ :Coimbatore Long, $\mathrm{L}_{5}$ :Green Long and $\mathrm{L}_{6}:$ VRBT-103) and four testers $\left(\mathrm{T}_{1}: \mathrm{IC}\right.$ 42261, $\quad \mathrm{T}_{2}$ :Chidambaram Small, $\mathrm{T}_{3}$ :Nanjangood Local and $\mathrm{T}_{4}$ :Panurthy) by using these parents twenty four $F_{1}$ hybrids were developed by adapting a line $\mathrm{x}$ tester ( $\mathrm{L}$ x T) analysis proposed by Kempthrone (1957) and were evaluated in Randomized Block Design (RBD) with three replications and MBTH-101 was used as commercial check.

Five randomly chosen plants in each replication of each entry were labelled and used for recording the observations. The mean of the five plants were taken for analysis. Observations were recorded at different stages of crop growth viz., 45, 60 and 90 days after sowing (DAS). Various growth characters and observations on flowering and fruit set were recorded at their respective stages.

\section{Results and Discussion}

Vine length is important growth parameter from productivity point of view. The ideal plant type should have longer vine length to support higher yield (Sirohi and Choudhari, 1978). The highest vine length at 45 $(109.66 \mathrm{~cm})$ and 60 DAS (152.16) was recorded in Panurthy among the parents. This was the second best for vine length at 90 DAS. At 90 DAS the vine length of the hybrids ranged from 218.22 to $296.28 \mathrm{~cm}$. It is interesting to know that the hybrid White Long $x$ Panurthy showed highest vine length at $45(114.47 \mathrm{~cm}), 60(159.91 \mathrm{~cm})$ and 90 DAS 
(296.28). In earlier studies also, same results were reported for vine length (Celine and Sirohi, 1996; Tewari and Ram, 1999; Singh et al., 2000, Danareddy, 2005 and Laxuman, 2005).

Earliness is an important trait in a vegetable like bitter gourd. Earliness is required in such crops for realizing the potential economic yield in as less time as possible which is an important consideration for a vegetable grower. In present study five characters related to earliness were observed viz., days to opening of first male flower, days to opening of female flower, number of node bearing first female flower, days to fifty per cent flowering and days to first harvest. A critical examination of the data on these characters in the material studied reveals the following things. The mean of the most of the hybrids in respect of all these characters lower than the corresponding mean values of the commercial check. This indicates that the hybrids evaluated were earlier compared to the standard check. Looking at the mean in respect of five characters indicate that extra earliness could be identified. For example Coimbatore Long $x$ Panurthy showed the lowest mean value of 37.32, 83.12 and 64.07 days to for days to opening of first male flower appearance, days to fifty per cent flowering and days to first fruit harvest compare to their corresponding mean values of $38.89,105.16$ and 70.41 days of the commercial check. Among the parents Chidambaram Small recorded the lowest mean values for day to first male and female flower appearance, days to first fruit harvest and days to fifty per cent flowering. Earlier workers also reported similar results for earliness (Tewari and Ram, 1999; Ram et al., 1997; Singh et al., 2000; Danareddy, 2005; Laxuman, 2005) (Table 1).

Primary branch is another important growth parameter contributing for productivity. The parents ranged from 7.09 (Green Long) to 10.30 (Chidambaram Small). The standard check had 9.00 mean number of primary branches compared to this $F_{1}$ hybrids exhibited mean number of primary branches ranging from 7.56 to 12.30 indicating that there is a difference between parental range and $F_{1} s$ range. The results are in agreement with those of Tewari and Ram (1999), Danareddy (2005) and Laxuman (2005).

For per cent fruit set, the parents range from 72.20 per cent (Arka Harit) to 88.01 per cent (Coimbatore Long). Majority of the hybrids showed relatively better performance compared to the commercial check. The hybrids Coimbatore Long $\mathrm{x}$ Panurthy and VRBT-100 x Panurthy showed highest mean values of 93.28 per cent and 92.33 per cent compared to check (83.95 per cent).

Sex ratio is also one of the important parameters, the mean value of most of the parents was less when compared to the standard check (18.17 per cent) except for Green Long (18.21 per cent), VRBT-103 (18.80 per cent) and also majority of the hybrids mean values were less than the standard check. However, highest mean value was found in the cross Green Long $x$ Nanjangood Local (21.95 per cent) (Table 2).

Number of seeds per fruit should be less to make it more acceptable to the consumer. Among the genotypes only five parents and 15 hybrids showed less than mean value compared to the standard check, which has than mean value of 21.9. However, it is important to know that range was quite high (12.3 to 28.27 seeds per fruit). Hybrid Arka Harit x Chidambaram Small with the mean number of seeds per fruit of 12.30 may be regarded as best for the number of seeds per fruit. Similar results reported by Celine and Sirohi (1996), Laxuman (2005) and Danareddy (2005) in bitter gourd. 
Table.1 Per se performance of parents and crosses for growth, earliness and yield parameters in bitter gourd

\begin{tabular}{|c|c|c|c|c|c|c|c|c|c|c|}
\hline Sl. No. & Crosses & $\begin{array}{c}\text { Vine } \\
\text { length at } 4 \\
\text { 5DAS }\end{array}$ & $\begin{array}{c}\text { Vine } \\
\text { length at } \\
60 \mathrm{DAS}\end{array}$ & $\begin{array}{c}\text { Vine } \\
\text { length at } \\
90 \text { DAS }\end{array}$ & $\begin{array}{l}\text { Productive } \\
\text { vine length }\end{array}$ & $\begin{array}{c}\text { Number of } \\
\text { primary } \\
\text { branches }\end{array}$ & $\begin{array}{c}\text { Days to } \\
\text { first male } \\
\text { flower } \\
\text { appearance }\end{array}$ & $\begin{array}{c}\text { Days to } \\
\text { first female } \\
\text { flower } \\
\text { appearance }\end{array}$ & $\begin{array}{c}\text { Node at } \\
\text { which first } \\
\text { female } \\
\text { flower } \\
\text { appears }\end{array}$ & $\begin{array}{c}\text { Number of } \\
\text { days for } 50 \\
\text { per cent } \\
\text { flowering }\end{array}$ \\
\hline 1. & $\overline{\mathrm{L}_{1} \times \mathrm{T}_{1}}$ & 84.26 & 124.84 & 259.50 & 283.08 & 9.11 & 39.32 & 61.33 & 8.07 & 98.67 \\
\hline 2. & $\mathrm{~L}_{1} \times \mathrm{T}_{2}$ & 81.33 & 118.01 & 249.01 & 259.10 & 9.33 & 37.70 & 51.35 & 8.75 & 90.27 \\
\hline 3. & $\mathrm{~L}_{1} \times \mathrm{T}_{3}$ & 97.71 & 129.76 & 264.38 & 338.13 & 8.16 & 39.79 & 64.60 & 7.99 & 102.05 \\
\hline 4. & $\mathrm{~L}_{1} \times \mathrm{T}_{4}$ & 101.84 & 143.46 & 281.54 & 345.98 & 9.06 & 37.39 & 50.25 & 12.60 & 84.36 \\
\hline 5. & $\mathrm{~L}_{2} \times \mathrm{T}_{1}$ & 55.90 & 96.87 & 232.99 & 226.26 & 9.20 & 39.31 & 59.29 & 8.16 & 94.16 \\
\hline 6. & $\mathrm{~L}_{2} \times \mathrm{T}_{2}$ & 43.00 & 86.14 & 218.22 & 162.69 & 9.84 & 38.35 & 50.40 & 7.37 & 84.70 \\
\hline 7. & $\mathrm{~L}_{2} \times \mathrm{T}_{3}$ & 59.02 & 102.94 & 237.39 & 220.64 & 8.85 & 39.59 & 58.92 & 6.39 & 102.60 \\
\hline 8. & $\mathrm{~L}_{2} \times \mathrm{T}_{4}$ & 67.18 & 112.98 & 243.04 & 227.60 & 10.55 & 40.32 & 57.58 & 10.60 & 101.17 \\
\hline 9. & $\mathrm{~L}_{3} \times \mathrm{T}_{1}$ & 78.63 & 126.31 & 258.06 & 286.09 & 9.01 & 39.75 & 57.58 & 8.54 & 104.22 \\
\hline 10. & $\mathrm{~L}_{3} \times \mathrm{T}_{2}$ & 72.96 & 122.13 & 252.16 & 209.78 & 10.60 & 38.95 & 50.66 & 9.65 & 87.88 \\
\hline 11. & $\mathrm{~L}_{3} \times \mathrm{T}_{3}$ & 103.26 & 147.36 & 279.21 & 322.56 & 8.80 & 40.08 & 58.67 & 11.96 & 102.98 \\
\hline 12. & $\mathrm{~L}_{3} \times \mathrm{T}_{4}$ & 114.47 & 159.91 & 296.28 & 325.55 & 9.31 & 38.89 & 59.87 & 10.92 & 102.35 \\
\hline 13. & $\mathrm{~L}_{4} \times \mathrm{T}_{1}$ & 71.89 & 108.06 & 244.11 & 273.08 & 9.14 & 38.87 & 60.58 & 14.58 & 108.19 \\
\hline 14. & $\mathrm{~L}_{4} \times \mathrm{T}_{2}$ & 61.24 & 102.90 & 236.37 & 258.17 & 11.80 & 39.68 & 51.62 & 8.68 & 87.47 \\
\hline 15. & $\mathrm{~L}_{4} \times \mathrm{T}_{3}$ & 84.07 & 132.99 & 264.32 & 307.79 & 9.44 & 39.91 & 63.14 & 10.63 & 113.40 \\
\hline 16. & $\mathrm{~L}_{4} \times \mathrm{T}_{4}$ & 84.73 & 137.15 & 278.18 & 321.12 & 10.15 & 37.32 & 50.13 & 11.42 & 83.12 \\
\hline 17. & $\mathrm{~L}_{5} \times \mathrm{T}_{1}$ & 78.05 & 121.40 & 251.21 & 262.58 & 7.56 & 40.32 & 59.68 & 7.71 & 105.87 \\
\hline 18. & $\mathrm{~L}_{5} \times \mathrm{T}_{2}$ & 69.80 & 107.95 & 232.99 & 231.97 & 8.86 & 37.44 & 50.69 & 5.86 & 87.25 \\
\hline 19. & $\mathrm{~L}_{5} \times \mathrm{T}_{3}$ & 87.10 & 134.37 & 261.05 & 284.77 & 8.15 & 40.29 & 61.08 & 10.92 & 105.65 \\
\hline 20. & $\mathrm{~L}_{5} \times \mathrm{T}_{4}$ & 88.62 & 137.93 & 273.05 & 296.21 & 8.29 & 37.41 & 59.15 & 9.06 & 98.52 \\
\hline 21. & $\mathrm{~L}_{6} \times \mathrm{T}_{1}$ & 66.89 & 107.06 & 248.16 & 260.74 & 10.15 & 39.97 & 61.30 & 10.07 & 108.52 \\
\hline 22. & $\mathrm{~L}_{6} \times \mathrm{T}_{2}$ & 60.42 & 103.09 & 234.05 & 219.68 & 12.30 & 38.31 & 51.50 & 8.51 & 87.15 \\
\hline
\end{tabular}


Table.1 Continued...

\begin{tabular}{|c|c|c|c|c|c|c|c|c|c|c|}
\hline Sl. No. & Crosses & $\begin{array}{l}\text { Vine length } \\
\text { at } 4 \text { 5DAS }\end{array}$ & $\begin{array}{l}\text { Vine length } \\
\text { at } 60 \text { DAS }\end{array}$ & $\begin{array}{c}\text { Vine } \\
\text { length at } \\
90 \text { DAS }\end{array}$ & $\begin{array}{l}\text { Productive } \\
\text { vine length }\end{array}$ & $\begin{array}{l}\text { Number } \\
\text { of } \\
\text { primary } \\
\text { branches }\end{array}$ & $\begin{array}{c}\text { Days to } \\
\text { first male } \\
\text { flower } \\
\text { appearance }\end{array}$ & $\begin{array}{c}\text { Days to } \\
\text { first female } \\
\text { flower } \\
\text { appearance }\end{array}$ & $\begin{array}{c}\text { Node at } \\
\text { which first } \\
\text { female } \\
\text { flower } \\
\text { appears }\end{array}$ & $\begin{array}{c}\text { Number } \\
\text { of days } \\
\text { for } 50 \text { per } \\
\text { cent } \\
\text { flowering }\end{array}$ \\
\hline 23. & $\mathrm{~L}_{1} \times \mathrm{T}_{1}$ & 76.71 & 128.00 & 263.76 & 261.30 & 9.15 & 40.87 & 63.95 & 10.07 & 111.47 \\
\hline \multirow[t]{2}{*}{24.} & $\mathrm{~L}_{1} \times \mathrm{T}_{2}$ & 92.15 & 142.21 & 276.11 & 309.15 & 10.60 & 40.46 & 62.40 & 14.55 & 110.27 \\
\hline & Lines & & & & & & & & & \\
\hline 1. & $\mathrm{~L}_{1}$ & 84.84 & 118.16 & 233.65 & 286.70 & 8.09 & 38.14 & 59.95 & 8.99 & 96.39 \\
\hline 2. & $\mathrm{~L}_{2}$ & 39.72 & 77.83 & 185.67 & 152.25 & 9.11 & 39.11 & 55.33 & 7.59 & 87.15 \\
\hline 3. & $\mathrm{~L}_{3}$ & 85.68 & 125.86 & 254.36 & 292.74 & 9.08 & 38.62 & 53.70 & 10.87 & 107.98 \\
\hline 4. & $\mathrm{~L}_{4}$ & 67.41 & 108.80 & 231.40 & 267.77 & 9.68 & 40.91 & 60.92 & 13.50 & 99.84 \\
\hline 5. & $\mathrm{~L}_{5}$ & 72.93 & 112.21 & 235.21 & 253.99 & 7.09 & 39.69 & 57.25 & 7.34 & 94.78 \\
\hline \multirow[t]{2}{*}{6.} & $\mathrm{~L}_{6}$ & 65.63 & 102.96 & 227.88 & 243.11 & 9.89 & 39.59 & 63.27 & 11.97 & 108.86 \\
\hline & Testers & & & & & & & & & \\
\hline 1. & $\mathrm{~T}_{1}$ & 62.32 & 102.16 & 220.94 & 255.07 & 8.01 & 40.56 & 64.82 & 10.89 & 94.66 \\
\hline 2. & $\mathrm{~T}_{2}$ & 31.00 & 57.17 & 161.56 & 101.36 & 10.30 & 38.50 & 51.88 & 5.42 & 83.86 \\
\hline 3. & $\mathrm{~T}_{3}$ & 94.86 & 139.96 & 267.95 & 342.71 & 7.12 & 42.24 & 70.97 & 9.03 & 98.36 \\
\hline \multirow[t]{4}{*}{4.} & $\mathrm{~T}_{4}$ & 109.66 & 152.16 & 291.26 & 359.22 & 8.74 & 41.54 & 65.91 & 14.25 & 98.42 \\
\hline & Mean & 76.33 & 118.56 & 248.38 & 266.14 & 9.25 & 39.57 & 58.83 & 9.79 & 99.11 \\
\hline & S.Em \pm & 0.3692 & 0.3808 & 0.4306 & 0.5644 & 0.0797 & 0.2406 & 0.2226 & 0.1874 & 1.5129 \\
\hline & C.D. at $5 \%$ & 1.0338 & 1.0662 & 1.2058 & 1.5803 & 0.2230 & 0.6738 & 0.6233 & 0.5248 & 4.2363 \\
\hline
\end{tabular}


Table.2 Per se performance of parents and crosses for growth, earliness and yield parameters in bitter gourd

\begin{tabular}{|c|c|c|c|c|c|c|c|c|c|}
\hline Sl. No. & Crosses & $\begin{array}{c}\text { Days to first } \\
\text { harvest }\end{array}$ & $\begin{array}{c}\text { Fruit length } \\
(\mathbf{c m})\end{array}$ & Sex ratio & $\begin{array}{l}\text { Per cent } \\
\text { fruit set }\end{array}$ & $\begin{array}{l}\text { Number of } \\
\text { Seeds fruit }^{-1}\end{array}$ & $\begin{array}{l}\text { Number of } \\
\text { fruits vine }^{-1}\end{array}$ & $\begin{array}{c}\text { Fruit } \\
\text { weight (g) }\end{array}$ & $\begin{array}{c}\text { Fruit yield } \\
\text { vine }^{-1}(\mathrm{~kg})\end{array}$ \\
\hline 1. & $\mathrm{~L}_{1} \times \mathrm{T}_{1}$ & 73.70 & 17.05 & 16.15 & 83.52 & 23.47 & 24.66 & 62.50 & 1.54 \\
\hline 2. & $\mathrm{~L}_{1} \times \mathrm{T}_{2}$ & 68.59 & 10.22 & 10.49 & 89.32 & 16.22 & 32.60 & 37.05 & 1.20 \\
\hline 3. & $\mathrm{~L}_{1} \times \mathrm{T}_{3}$ & 76.20 & 14.34 & 17.54 & 81.62 & 20.38 & 27.70 & 56.15 & 1.55 \\
\hline 4. & $\mathrm{~L}_{1} \times \mathrm{T}_{4}$ & 65.22 & 20.69 & 17.88 & 92.33 & 28.27 & 30.94 & 72.35 & 2.19 \\
\hline 5. & $\mathrm{~L}_{2} \times \mathrm{T}_{1}$ & 74.43 & 14.00 & 17.32 & 77.55 & 14.95 & 23.55 & 63.03 & 1.48 \\
\hline 6. & $\mathrm{~L}_{2} \times \mathrm{T}_{2}$ & 62.27 & 6.59 & 11.60 & 86.68 & 12.30 & 23.88 & 29.81 & 0.71 \\
\hline 7. & $\mathrm{~L}_{2} \times \mathrm{T}_{3}$ & 72.66 & 10.80 & 16.88 & 77.57 & 16.47 & 27.15 & 54.19 & 1.47 \\
\hline 8. & $\mathrm{~L}_{2} \times \mathrm{T}_{4}$ & 73.39 & 12.30 & 18.56 & 81.29 & 17.80 & 23.97 & 74.13 & 1.77 \\
\hline 9. & $\mathrm{~L}_{3} \times \mathrm{T}_{1}$ & 71.60 & 20.70 & 13.97 & 82.50 & 24.86 & 24.16 & 69.15 & 1.67 \\
\hline 10. & $\mathrm{~L}_{3} \times \mathrm{T}_{2}$ & 63.20 & 11.69 & 12.10 & 82.50 & 17.30 & 26.67 & 41.43 & 1.10 \\
\hline 11. & $\mathrm{~L}_{3} \times \mathrm{T}_{3}$ & 72.91 & 16.00 & 21.86 & 83.22 & 23.15 & 21.61 & 65.36 & 1.41 \\
\hline 12. & $\mathrm{~L}_{3} \times \mathrm{T}_{4}$ & 74.16 & 19.34 & 18.57 & 85.67 & 28.22 & 23.56 & 77.75 & 1.83 \\
\hline 13. & $\mathrm{~L}_{4} \times \mathrm{T}_{1}$ & 72.83 & 21.99 & 18.96 & 78.50 & 17.15 & 20.39 & 69.13 & 1.40 \\
\hline 14. & $\mathrm{~L}_{4} \times \mathrm{T}_{2}$ & 66.51 & 10.73 & 10.43 & 89.62 & 15.95 & 27.25 & 52.18 & 1.42 \\
\hline 15. & $\mathrm{~L}_{4} \times \mathrm{T}_{3}$ & 80.39 & 15.05 & 17.06 & 83.29 & 22.80 & 19.35 & 72.26 & 1.39 \\
\hline 16. & $\mathrm{~L}_{4} \times \mathrm{T}_{4}$ & 64.07 & 19.74 & 14.27 & 93.28 & 24.10 & 27.27 & 85.15 & 2.32 \\
\hline 17. & $\mathrm{~L}_{5} \times \mathrm{T}_{1}$ & 76.65 & 23.70 & 16.64 & 91.04 & 21.40 & 22.37 & 69.90 & 1.56 \\
\hline 18. & $\mathrm{~L}_{5} \times \mathrm{T}_{2}$ & 66.42 & 13.09 & 13.01 & 80.06 & 14.35 & 27.10 & 39.65 & 1.07 \\
\hline 19. & $\mathrm{~L}_{5} \times \mathrm{T}_{3}$ & 77.38 & 14.39 & 21.95 & 83.61 & 21.78 & 25.65 & 71.05 & 1.82 \\
\hline 20. & $\mathrm{~L}_{5} \times \mathrm{T}_{4}$ & 75.54 & 25.15 & 19.21 & 84.70 & 27.55 & 27.65 & 74.71 & 2.06 \\
\hline 21. & $\mathrm{~L}_{6} \times \mathrm{T}_{1}$ & 76.16 & 15.55 & 16.88 & 83.93 & 21.95 & 23.15 & 63.07 & 1.45 \\
\hline 22. & $\mathrm{~L}_{6} \times \mathrm{T}_{2}$ & 66.65 & 13.05 & 12.63 & 81.86 & 13.50 & 28.41 & 40.69 & 1.15 \\
\hline
\end{tabular}


Table.2 Continued...

\begin{tabular}{|c|c|c|c|c|c|c|c|c|c|}
\hline SI. No. & Crosses & $\begin{array}{c}\text { Days to first } \\
\text { harvest }\end{array}$ & $\begin{array}{c}\text { Fruit length } \\
\qquad(\mathrm{cm})\end{array}$ & Sex ratio & $\begin{array}{l}\text { Per cent } \\
\text { fruit set }\end{array}$ & $\begin{array}{l}\text { Number of } \\
\text { Seeds fruit }^{-1}\end{array}$ & $\begin{array}{l}\text { Number of } \\
\text { fruits vine }\end{array}$ & $\begin{array}{c}\text { Fruit } \\
\text { weight (g) }\end{array}$ & $\begin{array}{l}\text { Fruit yield } \\
\operatorname{vine}^{-1}(\mathrm{~kg})\end{array}$ \\
\hline 23 & & 777.14 & 16.00 & 21.85 & 82.96 & 20.53 & 22.55 & 55.55 & 1.25 \\
\hline \multirow[t]{2}{*}{24} & & 76.66 & 20.20 & 18.97 & 84.99 & 20.69 & 23.20 & 73.15 & 1.69 \\
\hline & Lines & & & & & & & & \\
\hline 1. & $\mathrm{~L}_{1}$ & 74.30 & 15.44 & 14.15 & 87.24 & 22.25 & 27.85 & 48.28 & 1.34 \\
\hline 2. & $\mathrm{~L}_{2}$ & 68.23 & 8.11 & 15.52 & 72.20 & 13.45 & 20.17 & 45.59 & 0.92 \\
\hline 3. & $\mathrm{~L}_{3}$ & 66.06 & 15.55 & 17.23 & 79.95 & 22.17 & 18.36 & 56.39 & 1.03 \\
\hline 4. & $\mathrm{~L}_{4}$ & 73.45 & 16.70 & 15.93 & 88.01 & 21.99 & 22.86 & 60.73 & 1.39 \\
\hline 5. & $\mathrm{~L}_{5}$ & 72.77 & 17.64 & 18.21 & 81.45 & 25.45 & 18.66 & 59.02 & 1.10 \\
\hline \multirow[t]{2}{*}{6.} & $\mathrm{~L}_{6}$ & 78.70 & 18.09 & 18.80 & 78.64 & 17.19 & 19.56 & 51.00 & 1.00 \\
\hline & Testers & & & & & & & & \\
\hline 1. & $\mathrm{~T}_{1}$ & 79.09 & 16.30 & 15.12 & 81.65 & 18.70 & 18.77 & 58.65 & 1.10 \\
\hline 2. & $\mathrm{~T}_{2}$ & 63.75 & 4.54 & 6.44 & 84.24 & 7.15 & 53.09 & 8.23 & 0.44 \\
\hline 3. & $\mathrm{~T}_{3}$ & 83.70 & 13.60 & 20.28 & 78.55 & 18.35 & 19.59 & 59.26 & 1.16 \\
\hline \multirow[t]{4}{*}{4.} & $\mathrm{~T}_{4}$ & 79.85 & 17.86 & 16.97 & 87.34 & 22.35 & 25.29 & 103.13 & 2.61 \\
\hline & Mean & 73.17 & 15.48 & 16.28 & 83.56 & 19.83 & 24.97 & 59.40 & 1.43 \\
\hline & S.Em \pm & 0.3723 & 0.2493 & 0.1247 & 0.4186 & 0.2019 & 0.2359 & 0.2919 & 0.0173 \\
\hline & C.D. at $5 \%$ & 1.0424 & 0.6981 & 0.3493 & 1.1722 & 0.5654 & 0.6607 & 0.8173 & 0.085 \\
\hline
\end{tabular}


For the character average fruit weight, the mean value of standard check had $70.67 \mathrm{~g}$ which is less than all parents except for Panurthy which has shown average fruit weight of $103.13 \mathrm{~g}$. On the other hand, mean value of only 8 hybrids recorded more than the standard check. The hybrid Coimbatore Long x Panurthy recorded maximum mean value of $85.1 \mathrm{~g}$. Similar results reported by Ranpise et al., (1992) and 8.09 percent by Danareddy (2005).

For average fruit length none of the parental mean value exceeds the standard check, which has $19.24 \mathrm{~cm}$ average fruit length. But there is wide range in hybrid mean value from $6.59 \mathrm{~cm}$ to $25.15 \mathrm{~cm}$. However, there is an interest to know that 8 hybrids mean value recorded more than the standard check. Coimbatore Long x Panurthy also recorded relatively high mean value. Laxuman (2005) and Danareddy (2005) reported heterosis for average fruit length.

Total yield per vine is mainly dependent on the number of fruits per vine and average fruit weight. For number of fruits per vine, only four parents exceed the mean value of standard check which is 21.18 fruits per vine. While, almost 22 hybrids exhibited higher mean value compared to standard check.

The hybrid VRBT-100 x Panurthy recorded second highest mean values. Coimbatore Long x Panurthy and Green Long x Panurthy also recorded relatively higher mean values. Earlier workers Danareddy (2005) and Laxuman (2005) reported heterosis for average fruit weight.

With regard to productive length, standard check had the mean value of $226.67 \mathrm{~cm}$ which is higher than all parents except Arka Hairt and Chidambaram Small. On the other hand, most of the hybrids exhibited higher mean value compared to the standard check. VRBT-
$100 \times$ Panurthy recorded the higher mean value of $345.98 \mathrm{~cm}$.

Yield per vine is the ultimate and the most important trait. Only one parental (Panurthy) mean value exceeds the mean value of the standard check which is $1.49 \mathrm{~kg}$. However, as much as 11 hybrids exhibited comparatively higher mean values than the standard check. Top three hybrids recorded highest per se performance are Coimbatore Long x Panurthy $(2.32 \mathrm{~kg})$, VRBT-100 x Panurthy $(2.19 \mathrm{~kg})$ and Green Long x Panurthy (2.06 kg) but these hybrids mean value slightly less than the top parent Panurthy $(2.61 \mathrm{~kg})$.

Interestingly all three of them involved Panurthy as one of the parent indicating the potentiality of Panurthy as a parental line for improving productivity. The other three parents involved in those hybrids being Coimbatore Long, VRBT-100 and Green Long.

The higher yield in these top three hybrids mainly attributed to earliness, higher average fruit weight and relatively higher number of fruits per vine.

\section{References}

Anonymous, 2013. Cultivation practices for Horticultural crops, University of Agricultural Sciences, Bangalore.

Behera, T.K. 2004. Heterosis in bitter gourd. J. New Seeds. 612/3): 217-222.

Celine, V.A. and Sirohi, P.S. 1996. Heterosis in bitter gourd (Momordica charantia L.). Veg. Sci., 2(2): 180-185.

Danareddy, T. 2005. Heterosis and combining ability studies in bitter gourd (Momordica charantia L.). M.Sc. (Agri.)Thesis, University of Agricultural Sciences, Dharwad.

Grubben, G. J. H. 1977. Tropical Vegetable and their Genetic Resources. IBPGR, 
Rome. p. 51-52.

Laxuman, 2005. Studies on diversity, heterosis and combining ability in bitter gourd (Momordica charantia L.). M.Sc.(Agri.) Thesis, University of Agricultural Sciences, Dharwad.

Miniraj, N., Prasanna, K.P. and Peter, K.V. 1993. Bitter gourd Momordica spp. In: Kalloo G, Bergh BO (eds) Genetic improvement of vegetable plants. Pergamon Press. Oxford. p. 239-246.

Ram, D., Kalloo, G. and Singh, M. 1997. Heterosis in bitter gourd (Momordica charantia L.). Veg. Sci., 24(2): 99-102

Raman, A Lau, C. 1996. Anti-diabetic properties and phytochemistry of Momordica charantia L. (Cucurbitaceae). Phytomedicine 2: 349362.

Ranpise, S. A., Kale, P.N., Desale, G.V. and Desai, U.T. 1992. Heterosis in bitter gourd (Momordica charantia L.). South
Indian Hort., 40(6): 313-315.

Singh, A.K. 1990. Cytogenetics and evolution in the Cucurbitaceae. In: Bates DM, Robinson RW Jeffrey C (eds) Biology and utilization of Cucurbitaceae. Cornell Univ Press. Ithaca, New York p. 11-28.

Singh, A.K., Pandey, U.B. and Singh, M. 2000. Studies on heterosis in bitter gourd. Veg. Sci., 27(2): 158-161.

Sirohi, P.S. and Choudhary, B. 1978. Heterosis in bitter gourd (Momordica charantia L.). Veg. Sci., 4(2): 107-115.

Tewari, D. and Ram, H.H. 1999. Heterosis in bitter gourd (Momordica charantia L.). Veg. Sci., 28(2): 106-108.

Welihinda, J., Karunanayake, E.M., Sheriff, M.H., Jayasinghe, K.S. 1986. Effect of Momordica charantia on the glucose tolerance in maturity onset diabetes. $J$. Ethnopharmacol 17: 277-282.

\section{How to cite this article:}

Sureshkumara, B., T.B. Puttaraju and Pavithra, H.B. 2017. Evaluation of Bitter Gourd (Momordica charantia L.) Hybrids under Eastern Dry Zone of Karnataka. Int.J.Curr.Microbiol.App.Sci. 6(11): 1931-1939. doi: https://doi.org/10.20546/ijcmas.2017.611.229 